\title{
Validitas Metode Polymerase Chain Reaction GeneXpert MTB/RIF pada Bahan Pemeriksaan Sputum untuk Mendiagnosis Multidrug Resistant Tuberculosis
}

\author{
Nurlina Sirait, ${ }^{1}$ Ida Parwati, ${ }^{2}$ Nina Susana Dewi, ${ }^{2}$ Nida Suraya ${ }^{2}$ \\ ${ }^{1}$ Laboratorium Patologi Klinik Rumah Sakit Sukadana Lampung Timur, ${ }^{2}$ Departemen Patologi Klinik \\ Fakultas Kedokteran Universitas Padjadjaran Rumah Sakit Dr. Hasan Sadikin Bandung
}

\begin{abstract}
Abstrak
Pengendalian tuberkulosis saat ini terkendala oleh metode diagnostik konvensional yang lambat terutama untuk mendeteksi multidrug resistant tuberculosis (MDR-TB). Deteksi dini MDR-TB sangat penting untuk mencegah penyebaran MDR-TB dan mengurangi angka kematian. Penelitian ini bertujuan menganalisis validitas pemeriksaan polymerase chain reaction genexpert MTB/RIF suatu pemeriksaan molekuler automatis yang cepat untuk mendeteksi MDR-TB. Penelitian dilakukan di Poliklinik Directly Observed Treatment ShortCourse (DOTS) Rumah Sakit Dr. Hasan Sadikin Bandung. Subjek penelitian adalah penderita tersangka MDRTB. Sampel penelitian berupa dahak yang dilakukan pemeriksaan mikroskopis, uji kepekaan metode proporsi media Lowenstein Jensen dan polymerase chain reaction genexpert MTB/RIF. Selama periode Agustus 2012 sampai Januari 2013 didapatkan 88 subjek penelitian, kelompok usia terbanyak 25-34 tahun. Hasil pemeriksaan kultur didapatkan 54 sampel tumbuh, 34 sampel tidak tumbuh, dan 3 sampel merupakan Mycobacteria lain dari tuberkulosis. Sebesar 97,5\% sampel yang resisten rifampisin juga resisten terhadap isoniazid. Pemeriksaan GeneXpert MTB/RIF menunjukkan sensitivitas 92,3\% dan spesifisitas 75\% dengan akurasi 88,2\%. Simpulan, pemeriksaan GeneXpert MTB/RIF memiliki validitas tinggi untuk mendiagnosis MDR-TB terhadap baku emas uji kepekaan $M$. tuberculosis metode proporsi pada media Lowenstein Jensen. Pemeriksaan ini disarankan sebagai alat skrining MDR-TB. [MKB. 2013;45(4):234-9]
\end{abstract}

Kata kunci: GeneXpert MTB/RIF, MDR-TB, uji kepekaan metode proporsi

\section{Validity of Polymerase Chain Reaction GeneXpert MTB/RIF Method on Sputum Sample Examination to Diagnose Multidrug Resistant Tuberculosis}

\begin{abstract}
Control of tuberculosis is hampered by slow conventional diagnostic methods especially for the detection of multidrug resistant tuberculosis (MDR-TB). Early detection of MDR-TB is essential to interrupt MDR-TB transmission and reduce the death rate. The aim of this study was to assess the validity of polymerase chain reaction genexpert MTB/RIF examination, which is a rapid automated molecular examination for the detection of MDR-TB. The study was conducted at the Directly Observed Treatment Short-Course (DOTS) clinic at Dr. Hasan Sadikin General Hospital Bandung. Subjects were patients with suspected MDR-TB. The research sample was sputum which was subjected to microscopic examination, susceptibility test proportion methods in Lowenstein Jensen media and polymerase chain reaction genexpert MTB/RIF examination. During August 2012 until January 2013, 88 subjects were obtained, with most of them were 25-34 years old. There were 54 samples obtained that grew in culture and 34 samples did not grow while 3 samples were other Mycobacteria of tuberculosis. It was also found that $97.5 \%$ of rifampin-resistant samples were also resistant to isoniazid. Examination of GeneXpert MTB/RIF showed a sensitivity of $92.3 \%$, specificity of $75 \%$ with an accuracy of $88.2 \%$. In conclusion, GeneXpert MTB/RIF examination has high validity for diagnosing MDR-TB against M. tuberculosis gold standard resistance test using the proportion method in Lowenstein Jensen media. The examination is recommended for MDR-TB screening. [MKB. 2013;45(4):234-9]
\end{abstract}

Key words: GeneXpert MTB/RIF,MDR-TB, susceptibility test proportion methods

Korespondensi: Nurlina Sirait, dr., Laboratorium Patologi Klinik Rumah Sakit Sukadana Lampung Timur, mobile 081379480396 e-mail geraldchess01@yahoo.com 


\section{Pendahuluan}

Tuberkulosis (TB) merupakan masalah kesehatan utama di dunia saat ini. Tantangan utama terhadap penanggulangan TB yaitu penyebaran galur TB yang resisten terhadap obat-obat antituberkulosis (OAT) atau disebut juga multidrug resistant tuberculosis (MDR-TB). ${ }^{1}$ Multidrug resistant TB adalah TB yang resisten terhadap paling sedikit terhadap dua OAT utama yaitu isoniazid (INH) dan rifampisin (Rif). ${ }^{1,2}$

Hanya sebagian kecil dari 440.000 penderita MDR-TB telah dilakukan uji kepekaan obat yang memadai. ${ }^{1,2}$ Masalah paling utama adalah metode diagnostik konvensional yang ada saat ini lambat dan rumit., ${ }^{3,4}$ Pertama diperlukan isolasi Mycobacterium tuberculosis (M. tuberculosis) pada spesimen, lalu diidentifikasi, dan dilanjutkan dengan uji kepekaan OAT tersebut. Pemeriksaan uji ini yang telah direkomendasikan World Health Organization (WHO) adalah metode proporsi dengan menggunakan media seperti Lowenstein Jensen, yang membutuhkan waktu 8-12 minggu. Selama kurun waktu tersebut penderita mendapat obat yang tidak tepat dan terjadi peningkatan jumlah M. tuberculosis mutan.., 5

Beberapa penelitian menyatakan lebih dari $90 \%$ penderita TB yang resisten rifampisin, juga mengalami resistensi terhadap isoniazid, sehingga resistensi terhadap rifampisin merupakan penanda pengganti (surrogate marker) yang mewakili suatu MDR-TB. ${ }^{6-9}$ Rifampisin bekerja dengan berikatan terhadap subunit- $\beta$ ribonucleic acid (RNA) polimerase yang dikode oleh gen $r p o B$, suatu komponen penting dalam proses transkripsi. Terhambatnya transkripsi RNA ini menyebabkan terhambatnya sintesis protein. Bila terjadi mutasi pada gen rрoB, maka obat rifampisin tidak dapat berikatan dengan subunit- $\beta$ RNA polimerase yang dikenal sebagai resistensi rifampisin. ${ }^{10-13}$ Beberapa peneliti mendapatkan $>95 \%$ isolat $M$. tuberculosis yang resisten terhadap rifampisin mengalami mutasi pada gen $r p o B$, sehingga regio ini merupakan target yang ideal untuk memeriksa resistensi rifampisin secara molekular. ${ }^{11,14,15}$

GeneXpert MTB/RIF merupakan pemeriksaan molekuler secara automatis untuk mendeteksi $M$. tuberculosis dan sekaligus mendeteksi resistensi M. tuberculosis terhadap rifampisin. Pemeriksaan ini menggunakan metode heminested real-time polymerase chain reaction (PCR) assay untuk mendeteksi mutasi pada regio hot spot rpoB, kemudian diperiksa dengan beacon molecular sebagai probe.,11-13 Pengujian dilakukan pada platform GeneXpert MTB/RIF, mengintegrasikan sampel yang akan diolah dalam cartridge plastik sekali pakai. Cartridge ini berisi semua reagen yang diperlukan untuk dapat melisiskan bakteri, ekstraksi asam nukleat, amplifikasi, dan deteksi gen yang sudah diamplifikasi. Hasil pemeriksaan dapat diperoleh dalam waktu 2 jam. Pemeriksaan ini bersifat automatis dan tidak perlu tenaga ahli khusus. ${ }^{10}$

Penelitian validitas metode PCR GeneXpert MTB/RIF sebagai alat untuk diagnostik MDRTB di Indonesia sampai saat ini belum pernah dilakukan. Mengingat bahwa penderita MDRTB semakin meningkat jumlahnya dan Indonesia merupakan negara dengan angka kejadian MDRTB yang tinggi, maka perlu dilakukan penelitian ini yang bertujuan untuk mengetahui validitas metode PCR GeneXpert MTB/RIF ini sebagai alat diagnostik cepat dengan subjek penelitian penderita tersangka MDR-TB yang datang ke poliklinik Directly Observed Treatment ShortCourse (DOTS) di Rumah Sakit Dr. Hasan Sadikin (RSHS) Bandung.

\section{Metode}

Subjek penelitian ini merupakan penderita yang didiagnosis sebagai tersangka MDR-TB paru yang berobat di poliklinik DOTS di RS Dr. Hasan Sadikin Bandung, baik sedang ataupun setelah memperoleh terapi OAT, telah menyetujui dan menandatangani persetujuan (informed consent).

Kriteria inklusi penelitian ini adalah penderita berusia $>18$ tahun dan sesuai kriteria tersangka MDR-TB yaitu penderita TB yang gagal terapi kategori 2, mendapat terapi kategori 2, tetapi tidak mengalami konversi basil tahan asam (BTA) setelah dua bulan pengobatan, penderita yang lalai berobat (default), penderita TB yang pernah diobati TB non-DOTS, penderita gagal terapi kategori 1, penderita mendapat pengobatan kategori 1 dan telah menjalani terapi sisipan tetapi tidak konversi, serta penderita TB yang kambuh. Kriteria eksklusi yaitu penderita yang tidak dapat mengeluarkan dahak.

Pemilihan subjek penelitian yang memenuhi kriteria inklusi tetapi tidak termasuk eksklusi dilakukan di poliklinik DOTS RSHS Bandung. Pengambilan bahan pemeriksaan dan pemeriksaan PCR GeneXpert MTB/RIF dilakukan di Divisi Mikrobiologi Klinik Departemen Patologi Klinik RSHS Bandung. Pemeriksaan kultur resistensi metode proporsi pada media Lowenstein Jensen dilakukan di Balai Pengembangan Laboratorium Kesehatan (BPLK) Provinsi Jawa Barat Bandung. Penelitian dilakukan dari Agustus 2012 sampai Januari 2013.

Penelitian ini merupakan penelitian potong lintang dengan bentuk deskriptif observasional. Analisis statistik yang dipakai yaitu uji diagnostik (sensitivitas, spesifisitas, nilai prediksi positif, 
nilai prediksi negatif, dan akurasi). Pemeriksaan PCR GeneXpert MTB/RIF menggunakan tabel 2x2 untuk mengukur validitas pemeriksaan PCR GeneXpert MTB/RIF yang dibandingkan dengan baku emas pemeriksaan resistensi dengan mempergunakan metode proporsi pada media Lowenstein Jensen.

\section{Hasil}

Selama kurun waktu enam bulan didapatkan 88 subjek. Data karakteristik subjek berupa usia, jenis kelamin, lama pengobatan, gejala klinis seperti batuk dan sesak, lalu dilaksanakan pemeriksaan mikroskopis BTA, biakan kultur dan uji kepekaan metode proporsi media Lowenstein Jensen serta pemeriksaan GeneXpert MTB/RIF. Pada Gambar terlihat dari 88 jumlah sampel penelitian yang dilakukan pemeriksaan kultur dan uji resistensi di BPLK, 34 sampel tidak tumbuh dalam media kultur dan didapatkan 54 sampel yang tumbuh dalam media kultur. Sampel penelitian sebanyak 54 sampel yang tumbuh tersebut, tiga sampel di antaranya dinyatakan sebagai Mycobacteria other than tuberculosis (MOTT) kemudian dikeluarkan dari sampel penelitian, sehingga hanya didapat
51 sampel yang terdiri atas 39 sampel MDR-TB dan 12 sampel non-MDR-TB. Pemeriksaan PCR GeneXpert MTB/RIF dilakukan pada 88 sampel penelitian menunjukkan hasil 22 sampel negatif M. tuberculosis dan 66 positif $M$. tuberculosis, dari hasil positif tersebut didapatkan 40 sampel resisten terhadap Rif dan 26 sampel ternyata sensitif terhadap Rif.

Data karakteristik jenis kelamin menunjukkan laki-laki lebih banyak bila dibandingkan dengan perempuan (56,8\%:43,2\%). Penderita terbanyak pada kelompok usia 25 sampai usia 34 tahun, seluruh penderita pernah mendapat pengobatan OAT antara 6 sampai 24 bulan, paling banyak mendapat pengobatan antara 13 sampai 18 bulan. Gejala klinis utama adalah batuk (88\%). Riwayat merokok didapatkan pada $50 \%$ penderita.

Berdasarkan data Tabel 2 terdapat resistensi terhadap Rif pada 40 sampel (78\%) dan sensitif terhadap Rif sebanyak 11 sampel (21\%). Angka resistensi dan sensitivitas terhadap INH ternyata sama dengan Rif yaitu $78 \%$ resisten INH dan $22 \%$ sensitif terhadap INH. Pada penelitian ini terdapat 1 sampel yang resisten terhadap Rif tetapi sensitif terhadap $\mathrm{INH}$, demikian pula terdapat 1 sampel yang resisten terhadap INH dan sensitif terhadap Rif. Terdapat 39 dari 40 sampel yang

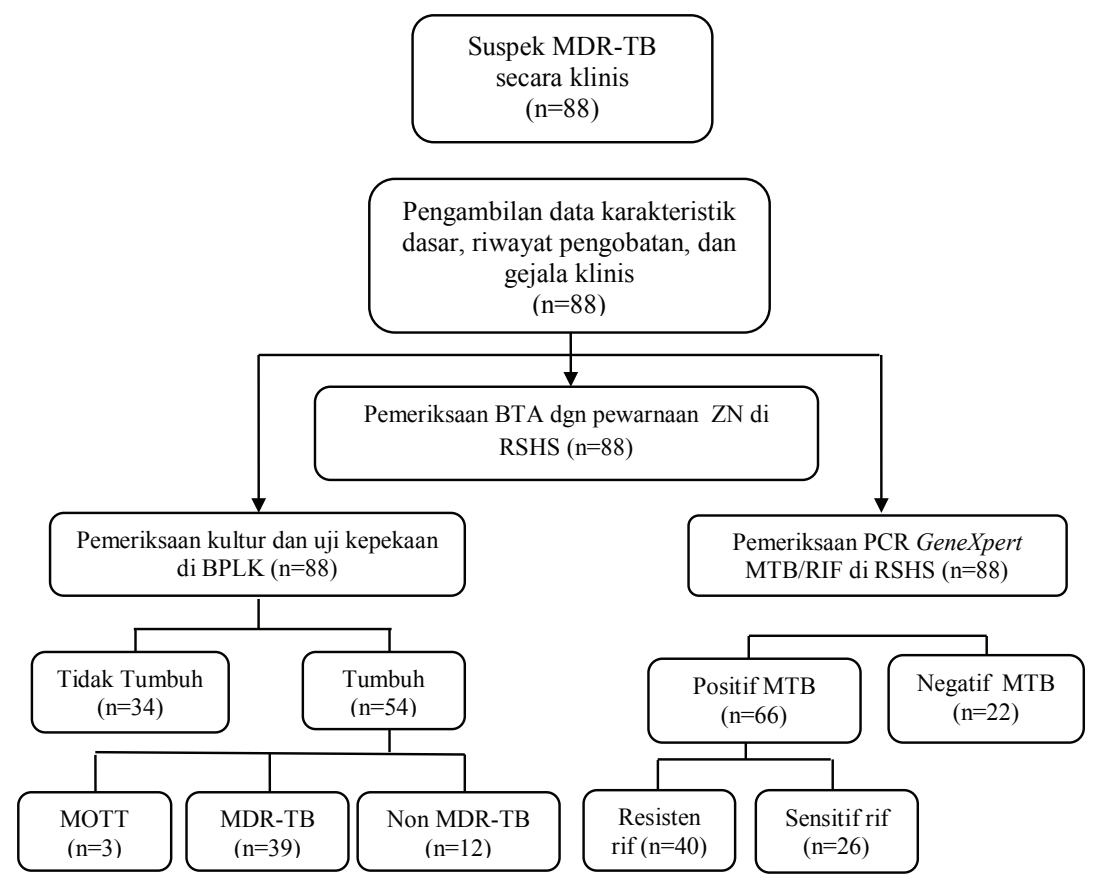

\section{Gambar Bagan Hasil Penelitian}

Keterangan: MDR-TB = multidrug resistant tuberculosis, BTA: batang tahan asam, ZN: ziehl neelsen, MOTT: mycobacteria other than tuberculosis, MTB: Mycobacterium tuberculosis, PCR: polymerase chain reaction 
Tabel 1 Karakteristik Subjek Penelitian

\begin{tabular}{|c|c|c|}
\hline Variabel & $\mathbf{n}$ & $\%$ \\
\hline \multicolumn{3}{|l|}{ Jenis kelamin } \\
\hline Laki-laki & 50 & 57 \\
\hline Perempuan & 38 & 43 \\
\hline \multicolumn{3}{|l|}{ Usia (tahun) } \\
\hline Rata-rata (SB) & 41,3 & 13 \\
\hline \multicolumn{3}{|c|}{ Usia kategori (tahun) } \\
\hline$<25$ & 6 & 7 \\
\hline $25-34$ & 24 & 27 \\
\hline $35-44$ & 22 & 25 \\
\hline $45-54$ & 21 & 24 \\
\hline $55-64$ & 12 & 14 \\
\hline$\geq 65$ & 3 & 3 \\
\hline \multicolumn{3}{|l|}{$\begin{array}{l}\text { Riwayat pengobatan } \\
\text { sebelumnya }\end{array}$} \\
\hline \multicolumn{3}{|c|}{ Lama pengobatan (bulan) } \\
\hline 6 & 3 & 3 \\
\hline $7-12$ & 22 & 25 \\
\hline $13-18$ & 29 & 33 \\
\hline $19-24$ & 19 & 22 \\
\hline$>24$ & 15 & 17 \\
\hline \multicolumn{3}{|l|}{ Gejala klinis } \\
\hline Batuk & 88 & 100 \\
\hline Sesak & 67 & 76 \\
\hline Riwayat merokok & 44 & 50 \\
\hline
\end{tabular}

menunjukkan resistensi Rif juga menunjukkan resistensi INH, atau terdapat $98 \%$ penderita yang resisten terhadap Rif, resisten juga terhadap INH.

Tabel 3 menunjukkan hasil sensitivitas dan spesifisitas pemeriksaan PCR GeneXpert MTB/ RIF dibandingkan dengan baku emas kultur metode proporsi pada media Lowenstein Jensen dalam mendeteksi resistensi Rif. Sampel yang dianalisis sebanyak 51 sampel yang sesuai dengan
Tabel 2 Uji Kepekaan Rif dan INH

\begin{tabular}{clcc}
\hline Uji Kepekaan & \multicolumn{1}{c}{ Hasil } & $\mathbf{n = 5 1}$ & $\mathbf{\%}$ \\
\hline Resistensi Rif & Sensitif Rif & 11 & 22 \\
& Resisten Rif & 40 & 78 \\
& Total & 51 & 100 \\
Resistensi INH & Sensitif INH & 11 & 22 \\
& Resisten INH & 40 & 78 \\
& Total & 51 & 100 \\
\hline
\end{tabular}

jumlah sampel yang tumbuh pada media kultur dan tidak termasuk MOTT. Tabel 3 menunjukkan hasil uji sebagai berikut:

$\begin{array}{ll}\text { Sensitivitas } & : 92,5 \% \\ \text { Spesifisitas } & : \quad 81,8 \% \\ \text { Nilai duga positif (NDP) } & : 94,9 \% \\ \text { Nilai duga negatif (NDN) } & : 75,0 \% \\ \text { Akurasi } & : 90,2 \%\end{array}$

\section{Pembahasan}

Pada penelitian didapatkan 39 dari 40 sampel yang resisten Rif juga resisten terhadap INH berdasarkan hasil uji kepekaan metode proporsi media Lowenstein Jensen sebagai baku emas pemeriksaan, atau terdapat $98 \%$ penderita yang resisten terhadap Rif, resisten juga terhadap INH. Keadaan ini ternyata tidak jauh berbeda dengan penelitian yang dilakukan Caws dkk. ${ }^{8}$ di Vietnam mendapatkan $98 \%$ penderita yang mengalami resistensi terhadap Rif, resisten juga terhadap INH. Berdasarkan hasil ini, pemeriksaan PCR GeneXpert MTB/RIF pada penelitian ini dapat digunakan sebagai pemeriksaan untuk menentukan MDR-TB.

Tiga dari 51 sampel penelitian menunjukkan hasil sensitif terhadap Rif pada pemeriksaan PCR GeneXpert MTB/RIF, namun menunjukkan hasil resisten terhadap Rif dan INH pada uji kepekaan

Tabel 3 Validitas Pemeriksaan PCR GeneXpert MTB/RIF Mendeteksi Resistensi Rif Dibandingkan dengan Baku Emas Kultur

\begin{tabular}{lccc}
\hline \multirow{2}{*}{ PCR GeneXpert MTB/RIF } & \multicolumn{3}{c}{ Uji Kepekaan Metode Proporsi Media Lowenstein Jensen } \\
\cline { 2 - 4 } & Resisten Rif & Sensitif Rif & Total \\
\hline Resisten Rif & 37 & 2 & 39 \\
Sensitif Rif & 3 & 9 & 12 \\
Total & 40 & 11 & 51 \\
\hline
\end{tabular}


metode proporsi, hal ini disebut negatif palsu pada hasil pemeriksaan PCR GeneXpert MTB/ RIF. Nilai negatif palsu ini memengaruhi nilai sensitivitas pada penelitian ini yaitu $92,3 \%$.

Pemeriksaan PCR GeneXpert MTB/RIF ini menilai mutasi pada regio hot spot gen $r p o B$ yang menunjukkan resistensi terhadap Rif. Beberapa penelitian sebelumnya menyatakan bahwa $95 \%$ M. tuberculosis mengalami mutasi pada region hot spot gen rрoB akan menyebabkan resistensi terhadap obat Rif, namun diperkirakan sebanyak $5 \% M$. tuberculosis yang resisten terhadap Rif mengalami mutasi di luar regio hot spot gen $r p o B .{ }^{14-17}$ Negatif palsu yang didapatkan pada penelitian ini mungkin disebabkan mutasi di luar regio hot spot gen rpoB, sehingga dibutuhkan penelitian yang lebih lanjut untuk membuktikan penyebab negatif palsu ini.

Penelitian yang dilakukan oleh Yue $\mathrm{dkk} .{ }^{18} \mathrm{di}$ Cina tahun 2003, mendapatkan dari 72 sampel yang resisten terhadap Rif dengan pemeriksaan uji kepekaan pada media Lowenstein Jensen, didapatkan 7 sampel (9,7\%) mengalami mutasi di luar regio hot spot gen rpoB. Kemungkinan lain penyebab negatif palsu seperti yang didapatkan pada penelitian Lawn dan $\mathrm{Nicol}^{10}$ tahun 2011, bila terjadi infeksi campuran $M$. tuberculosis yang masih sensitif dengan yang resisten Rif. Jika $M$. tuberculosis yang sensitif jumlahnya lebih banyak, maka resistensi Rif tidak dapat dideteksi. Spesifisitas GeneXpert MTB/RIF dibandingkan dengan baku emas kultur metode proporsi pada media Lowenstein Jensen untuk mendeteksi MDR-TB nilainya sampai sebesar $75,0 \%$. Nilai ini berbeda dengan beberapa penelitian serupa yang pernah dilakukan di antaranya oleh Boehme dkk. ${ }^{11}$ yang mendapatkan spesifisitas 98,0\%. Nilai spesifisitas GeneXpert MTB/RIF ditentukan oleh nilai positif palsu, yaitu bila hasil pemeriksaan PCR GeneXpert MTB/RIF menunjukkan resisten terhadap Rif namun hasil uji kepekaan metode proporsi menunjukkan hasil sensitif terhadap Rif dan INH.

Hasil penelitian ini mendapatkan 3 pada 51 subjek penelitian menunjukkan hasil positif palsu. Positif palsu pada pemeriksaan PCR GeneXpert MTB/RIF dapat disebabkan karena terlambatnya probe yang menempel pada target. Hal ini pernah dilaporkan pada penelitian yang dilakukan oleh Marlowe dkk. ${ }^{19}$ di Amerika tahun 2011. Pada 130 sampel yang sensitif terhadap Rif berdasarkan uji kepekaan konvensional, terdapat 3 sampel resisten Rif dengan PCR GeneXpert MTB/RIF, setelah dilakukan sekuensing terhadap 3 sampel tersebut tidak ditemukan mutasi pada gen rpo $B$. Keadaan yang sama juga pernah ditemukan pada penelitian yang dilakukan Lawn dan Nicol dkk. ${ }^{10}$ di Afrika tahun 2011, dari 55 sampel yang sensitif
Rif dengan uji kepekaan konvensional, pada PCR GeneXpert MTB/RIF terdeteksi resisten Rif, kemudian dilakukan sekuensing tetapi tidak ditemukan mutasi pada gen rpoB. Hasil positif palsu pada penelitian ini dapat disebabkan karena terlambatnya probe menempel pada targetnya, sehingga dibutuhkan penelitian lebih lanjut untuk memastikan penyebab positif palsu ini.

Penyebab lain spesifisitas yang rendah pada penelitian ini adalah banyaknya sampel yang tidak tumbuh pada media kultur. Terdapat 12 sampel yang pada pemeriksaan PCR GeneXpert MTB/ RIF menunjukkan positif $M$. tuberculosis namun ternyata tidak tumbuh pada saat dikultur, sehingga tidak dapat dianalisis. Sampel yang tidak tumbuh pada media kultur ini dapat disebabkan penderita tersangka MDR-TB ini sedang menjalani terapi TB yang menyebabkan viabilitas $M$. tuberculosis berkurang sehingga tidak dapat tumbuh dalam media kultur.

Mycobacteria other than tuberculosis atau MOTT pada penelitian ini terdapat pada 3 dari 54 sampel yang tumbuh di media kultur. Hal ini kemungkinan dapat disebabkan infeksi campuran M. tuberculosis complex dan MOTT tetapi karena pertumbuhan MOTT lebih cepat dibandingkan dengan $M$. tuberculosis complex, sehingga hasil kultur lebih banyak MOTT tumbuh dibandingkan dengan $M$. tuberculosis complex. Untuk dapat menentukan MOTT tersebut dilakukan uji niasin, didapatkan hasil pemeriksaan negatif. Hal lain yang dapat menyebabkan MOTT yaitu terjadi kontaminasi karena MOTT ini dapat ditemukan dalam lingkungan seperti air, tanah, dan dapat membentuk kolonisasi pada kulit normal.

Berdasarkan uji validitas di atas, pemeriksaan metode PCR GeneXpert MTB/RIF menggunakan bahan pemeriksaan sputum memiliki validitas yang tinggi terhadap baku emas uji kepekaan metode proporsi dengan media Lowestein Jensen. Metode ini dapat digunakan sebagai alat skrining karena mempunyai sensitivitas yang tinggi.

\section{Daftar Pustaka}

1. WHO. Rapid implementation of the Xpert MTB/RIF diagnostic test. Geneva: WHO; 2011.

2. WHO. Multidrug and extensively drugresistant TB (M/XDR-TB) 2010 Global report on surveillance and response. Geneva: WHO; 2010.

3. O'Grady J, Maeurer M, Mwaba P, Kapata $\mathrm{N}$, Bates M, Hoelscher M, dkk. New and improved diagnostics for detection of drugresistant pulmonary tuberculosis. Curr Opin Pulm Med. 2011;17(3):134-41. 
4. WHO. Molecular line probe assay for rapid screening of patients at risk of multidrug resistant tuberculosis (MDR-TB). Geneva: WHO; 2008.

5. Chiang CY, Centis R, Migliori GB. Drugresistant tuberculosis: past, present, future. Respirology. 2010;15(3):413-32.

6. Trébucq A, Enarson DA, Chiang CY, Van Deun A, Harries AD, Boillot F, dkk. Xpert ${ }^{\circledR}$ MTB/RIF for national tuberculosis programmes in low-income countries: when, where and how? Int J Tuberc Lung Dis. 2011;15(12):1567-72.

7. Ramirez MV, Cowart KC, Campbell PJ, Morlock GP, Sikes D, Winchell JM, dkk. Rapid detection of multidrug-resistant Mycobacterium tuberculosis by use of realtime PCR and high-resolution melt analysis. J Clin Microbiol. 2010;48(11):4003-9.

8. Caws M, Duy PM, Tho DQ, Lan NT, Hoa DV, Farrar J. Mutations prevalent among rifampin and isoniazid resistant Mycobaterium tuberculosis isolates from a hospital in Vietnam. J Clin Microbiol. 2006;44(7):2333-7.

9. Sekiguchi J, Miyoshi-Akiyama T, Augustynowicz-Kopec E, Zwolska Z, Kirikae F, Toyota E, dkk. Detection of multidrug resistance in Mycobacterium tuberculosis. J Clin Microbiol. 2007;45(1):179-92.

10. Lawn SD, Nicol MP. Xpert ${ }^{\circledR}$ MTB/RIF assay: development, evaluation and implementation of a new rapid molecular diagnostic for tuberculosis and rifampicin resistance. Future Microbiol. 2011;6(9):1067-82.

11. Boehme CC, Nabeta P, Hillemann D, Nicol MP, Shenai S, Krapp F, dkk. Rapid molecular detection of tuberculosis and rifampin resistance. N Engl J Med. 2010;363:1005-15.

12. Mitchison DA. Drug resistance in tuberculosis. Eur Respir J. 2005;25(2):376-9.

13. Hillemann D, Weizenegger M, Kubica T,
Richter E, Niemann S. Use of the genotype MTBDR assay for rapid detection of rifampin and isoniazid resistance in Mycobacterium tuberculosis complex isolates. J Clin Microbiol. 2005;43(8):3699-703.

14. Pietzka AT, Indra A, Stoger A, Zeinzinger J, Konrad M, Hasenberger P, dkk. Rapid identification of multidrug-resistant Mycobacterium tuberculosis isolates by rpoB gene scanning using high-resolution melting curve PCR analysis. J Antimicrob Chemother. 2009;63(6):1121-7.

15. Li J, Xin J, Zhang L, Jiang L, Cao H, Li L. Rapid detection of rpoB mutations in rifampin resistant M. tuberculosis from sputum samples by denaturing gradient gel electrophoresis. Int J Med Sci. 2012;9(2):148-56.

16. Chang K, Lu W, Wang J, Zhang K, Jia S, $\mathrm{Li} \mathrm{F}$, dkk. Rapid and effective diagnosis of tuberculosis and rifampicin resistance with Xpert MTB/RIF assay: a meta-analysis. J Infect. 2012;64(6):580-8.

17. Teo J, Juareen R, Chiang D, Chan D, Lin R. Comparison of two nucleic acid amplification assays, the Xpert MTB/RIF assay and the amplified Mycobacterium tuberculosis direct assay, for detection of Mycobacterium tuberculosis in respiratory and nonrespiratory specimens. J Clin Microbiol. 2011;49(10):3659-62.

18. Yue J, Shi W, Xie J, Li Y, Zeng E, Wang H. Mutations in the rpoB gene of multidrugresistant Mycobacterium tuberculosis isolates from China. J Clin Microbiol. 2003;41(5):2209-12.

19. Marlowe EM, Novak-Weekley SM, Cumpio J, Sharp SE, Momeny MA, Babst A. dkk. Evaluation of the Cepheid Xpert MTB/RIF assay for direct detection of Mycobacterium tuberculosis complex in respiratory specimens. J Clin Microbiol. 2011;49(4):1621-3. 


\title{
Hubungan Imunoekspresi CD34 dengan Gradasi dan Stadium (Duke) pada Adenokarsinoma Kolorektal
}

\author{
Herry Yulianti, Bethy S. Hernowo \\ Departemen Patologi Anatomi Fakultas Kedokteran Universitas Padjadjaran \\ Rumah Sakit Dr. Hasan Sadikin Bandung
}

\begin{abstract}
Abstrak
Karsinoma kolorektal umum terjadi di Eropa Barat Laut dan Amerika Utara, tetapi rendah di Afrika, Asia, dan Amerika Selatan. Di Indonesia, karsinoma kolorektal merupakan masalah kesehatan masyarakat dan merupakan tiga penyakit kanker terbanyak. Angiogenesis adalah pertumbuhan dan proliferasi pembuluh darah baru dari pembuluh darah yang sudah ada. Secara imunohistokimia, mikrovaskular dapat diidentifikasi dengan menggunakan monoklonal cluster of differentiation (CD34) antibodi. Pada beberapa penelitian, microvascular density (MVD) berhubungan dengan gradasi histologi, stadium, metastasis, dan prognosis tumor. Tujuan penelitian ini untuk mengetahui hubungan ekspresi CD34 dengan gradasi dan stadium (klasifikasi Duke) pada karsinoma kolorektal. Metode penelitian adalah cross sectional terhadap 40 kasus adenokarsinoma kolorektal yang berasal dari Departemen Patologi Anatomi Rumah Sakit Dr. Hasan Sadikin Bandung-Fakultas Kedokteran Universitas Padjadjaran tahun 2004-2005. Potongan blok parafin dari jaringan kolorektal karsinoma diwarnai dengan hematoksilin eosin untuk evaluasi histologi dan imunohistokimia menggunakan monoclonal CD34 antibody. Penghitungan MVD yang imunoreaktif dilakukan di bawah mikroskop cahaya dengan pembesaran 400x, dihitung rata-rata pada 5 tempat daerah neovaskularisasi yang paling padat. Hasil penelitian menunjukkan hubungan yang signifikan MVD dengan stadium $(\mathrm{p}<0,01)$ dan tidak ada hubungan yang signifikan antara MVD dan gradasi $(\mathrm{p}<0,05)$. Simpulan, hubungan MVD dengan kedalaman invasi dan metastasis ke kelenjar limfe yang dinilai dengan klasifikasi Duke dan CD34 dapat digunakan untuk memprediksi prognosis, memperkirakan kemungkinan metastasis melalui pembuluh darah, dan memprediksi respons terhadap terapi antiangiogenik. [MKB. 2013;45(4):240-4]
\end{abstract}

Kata kunci: Adenokarsinoma kolorektal, CD34, gradasi, klasifikasi Duke

\section{Correlation between CD34 Immunoexpression and Colorectal Adenocarcinoma Grade and Stage (Duke)}

\begin{abstract}
Carcinoma colorectal is commonly found in Nortwest Europe and North America, but not frequently found in Africa, Asia and South America. Colorectal cancer (CRC) is a public health problem in Indonesia and currently ranks among the three most common cancers. Angiogenesis is the growth and proliferation of new blood vessels from existing vasculature. Microvessels were identified immunohistochemically using monoclonal cluster of differentiation (CD34) antibody. Several studies have noted that microvascular density (MVD) correlates with stage of disease, histological grade, metastasis, and prognosis in cancers. The aim of this study was to explore the relation between CD34 immunoexpresion and grade and stage (Duke classification) in colorectal adenocarcinoma. This is a cross sectional study with 40 colorectal carcinoma cases from Department of Pathology Anatomy, Dr. Hasan Sadikin General Hospital/Faculty of Medicine, Universitas Padjadjaran Bandung during 2004-2005. A section from paraffin embedded tissue of colorectal carcinoma was stained with hematoxylin eosin for histological and immunohistochemical evaluations using monoclonal CD34 antibody. Microvascular density was counted in five tumor areas with most intensive neovascularization using 400x field light microscopy. A significant correlation was found between the MVD and stage $(p<0.01)$ while no significant relationship found between MVD and different grade $(\mathrm{p}<0.05)$. In conclusion, correlations are found between MVD with tumor invation depth and lymph node metastases determined by the Duke' staging system and CD34 can be used to predict prognosis, possibility of hematogenous metastases and responses to antiangiogenic therapy. [MKB. 2013;45(4):240-4]
\end{abstract}

Key words: Adenocarcinoma colorectal, CD34, Duke clasification, grade

Korespondensi: Herry Yulianti, dr., Sp.PA, Jalan Guntursari III no 21 Buah Batu Bandung (40264), Telepon (022)7310164 mobile 0811223103 e-mail herryyulianti@yahoo.com 